\title{
IRENE CANFORA
}

\section{Certyfikacja i ochrona jakości produktów rolno-żywnościowych*}

Certyfikacja produktów rolno-żywnościowych wysokiej jakości jest dynamicznie rozwijającym się zjawiskiem ekonomicznym, które stanowi odpowiedź na zapotrzebowanie ze strony konsumentów poszukujących produktów o właściwościach powiązanych $\mathrm{z}$ procesem produkcji ${ }^{1}$. Jeśli ograniczy się to zagadnienie do rozważenia treści certyfikacji skierowanej na rynek docelowy (i pominie certyfikacje obowiązujące wewnątrz łańcucha dostaw), to przedmiot certyfikacji dotyczy właściwości ekologicznych lub środowiskowych produktów (począwszy od produkcji ekologicznych aż po te pochodzące $\mathrm{z}$ rolnictwa integrowanego). W niektórych przypadkach będzie się to wyrażało pominięciem właściwości produktu (jak w przypadku produktów, które nie zawierają GMO), a w innych zaś odwołaniem do poszanowania wartości etycznych (jak np. dla produktów w ramach sprawiedliwego handlu, które potwierdzają rzeczywistą dochodowość wytwórczej działalności rolniczej wykonywanej w krajach rozwijających się oraz zapewnienie odpowiednich warunków pracy). Wreszcie niektóre certyfikacje odnoszą się do procedur wytwarzania środków spożywczych zgodnie z nakazami religijnymi (jak ma to miejsce w przypadku uregulowań w Wielkiej Brytanii, gdzie takie informacje umieszcza się na

* Artykuł stanowi rozszerzoną wersję referatu pt. „Certificazione e tutela della qualitá dei prodotti agroalimentari" wygłoszonego na V Polsko-Włoskiej Konferencji Naukowej/ V Giornate polacco-italiane, zatytułowanej „Prawo rolne wobec współczesnych wyzwań/ Il diritto agrario di fronte alle sfide contemporanee”, która odbyła się we wrześniu 2014 r. w Obrzycku k. Poznania (tłumaczenie: dr Edyta Bocian).

${ }^{1} \mathrm{~W}$ niektórych przypadkach narzucona przez przedsiębiorstwa w celu zróżnicowania popytu na rynku, w innych ponownie opracowana w wyniku potrzeb wychodzących od grup konsumentów celem zdobycia nowych segmentów rynku. 
etykiecie produktów żywnościowych, gdyż przewidziano tam w sposób wyraźny uregulowania dotyczące mięsa halal).

W płaszczyźnie prawnej zjawisko to wpływa na zasadność wprowadzenia ram regulacyjnych dla tych sektorów, które nie zostały jeszcze prawnie uregulowane. Temat ten został już omówiony w Zielonej księdze w sprawie jakości produktów rolnych z 15 października 2008 r., która starała się odpowiedzieć na podstawowe pytanie, czy i w jaki sposób uregulować prywatne certyfikacje produktów spożywczych, bez uszczerbku dla obecności urzędowych certyfikacji już uregulowanych i ujednoliconych w prawie europejskim. Uogólniając, można by powiedzieć, że konsultacje z 2008 r. przyniosły wyniki idące w dwóch kierunkach.

$\mathrm{Z}$ jednej strony poszerzył się zakres europejskich systemów jakości przez wprowadzenie w rozporządzeniu (UE) nr 1151/2012 z 21 listopada 2012 r. w sprawie systemów jakości produktów rolnych i środków spożywczych $^{2}$ fakultatywnych określeń, takich jak ,,produkty górskie” oraz ,produkty wyspiarskie". Następstwem tego było zaliczenie ich do określeń „uznawanych” przez prawo europejskie, ale bez objęcia ich taką samą strukturą normatywna, jak ta przewidziana w zakresie certyfikacji pozostałych charakterystycznych znaków jakości. $Z$ drugiej strony, w kwestii dobrowolnych systemów certyfikacji, opowiedziano się za niewiążącym rozwiązaniem normatywnym - przyjęto Wytyczne UE dotyczące najlepszych praktyk dla dobrowolnych systemów certyfikacji produktów rolnych i środków spożywczych ${ }^{3}$.

Wybór ten doprowadził do rezygnacji ze sztywnych uregulowań prywatnych działań certyfikujących ${ }^{4}$, do czego niewątpliwie przyczyniła się okoliczność, że systemy certyfikacji posiadają znaczenie ponadnarodowe. Wspomniany dokument ogranicza się istotnie do potwierdzenia, w zakresie wszystkich systemów certyfikacji w żaden inny sposób nieuregulowanych przez prawo europejskie, zasad prawidłowego działania rynku, jak poszanowanie zasad odnoszących się do rynku wewnętrznego, konkurencji oraz przejrzystość informacji. Chodzi w istocie o odwołania do ogólnych

${ }^{2}$ Dz. Urz. UE L 343/1 z 14 grudnia 2012 r.

${ }^{3}$ Zob. Komunikat Komisji opublikowany w Dz. Urz. UE 2010 C 341/04.

${ }^{4}$ W Wytycznych (pkt 1.2) można przeczytać: „W komunikacie w sprawie polityki jakości produktów rolnych Komisja wyraziła opinię, że w świetle zmian i inicjatyw w sektorze prywatnym, celem opracowywanych przez nią aktów ustawodawczych na tym etapie nie jest zajęcie się słabymi stronami prywatnych systemów certyfikacji. Zamiast tego - w oparciu o uwagi zainteresowanych podmiotów - Komisja zobowiązała się do opracowania, w porozumieniu z grupa doradczą do spraw jakości, wytycznych dla systemów certyfikacji produktów rolnych i środków spożywczych". 
i już utwierdzonych zasad, które nie pociagają za sobą znacznych zmian w odniesieniu do działań certyfikujących podejmowanych przez podmioty prywatne.

Sytuacja, w której systemy certyfikacji są wspierane przez podmioty publiczne, jest delikatniejsza. W tym przypadku, mając zwłaszcza na uwadze certyfikację produktów żywnościowych, Komisja dostrzega główny punkt sporny w postaci potencjalnych przeszkód swobodnego przepływu towarów, będących właśnie następstwem certyfikacji produktów. Komisja wskazuje, że ,władze krajowe lub regionalne nie mogą prowadzić do ograniczeń dotyczących pochodzenia producentów lub w inny sposób utrudniać obrotu handlowego na jednolitym rynku" .

To postanowienie stanowi kryterium uregulowania certyfikacji w relacjach pomiędzy państwami członkowskimi a Unią Europejską. Istotnie margines interwencji państw członkowskich dotyczący krajowej regulacji zasad certyfikacji jest dopuszczany tylko w zakresie pomocniczym, gdy brak ujednolicenia, ale zawsze z poszanowaniem art. 28 TfUE.

Jest to jeszcze bardziej oczywiste, jeżeli zestawi się zalecenia zawarte w Wytycznych ze swego rodzaju „klauzulą bezpieczeństwa” zasad jednolitego rynku, przewidziana przez art. 28 rozporządzenia $\mathrm{nr}$ 1151/2012 i odnoszącą się do urzędowych certyfikacji, które państwa członkowskie zamierzają zachować lub wprowadzić, poza tymi fakultatywnymi, które są obecnie zawarte wśród ,systemów jakości”. Również w tym przypadku występuje odesłanie do zasady zakazu tworzenia przeszkód dla swobodnego przepływu towarów: „Państwa Członkowskie mogą utrzymać krajowe przepisy dotyczące określeń jakościowych stosowanych fakultatywnie, nieobjętych niniejszym rozporządzeniem, pod warunkiem że takie przepisy są zgodne z prawem unijnym".

W tym zróżnicowanym obrazie całości urzędowe certyfikacje normowane przez prawo europejskie stanowią regulację już dawno wprowadzoną. Warto przeanalizować jej etapy ewolucyjne, aby ująć jednostki certyfikujące w kontekście celów, których osiągnięciu mają służyć systemy ochrony jakości. Wśród nich najbardziej interesująca jest certyfikacja produktów ekologicznych.

Łatwo zauważyć, że „model” certyfikacji pierwotnie stworzony przez rozporządzenie Rady (EWG) 2092/91 z 24 czerwca 1991 r. w sprawie produkcji ekologicznej produktów rolnych oraz znakowania produktów rolnych i środków spożywczych ${ }^{6}$ nadal zachowuje swoją autonomię, po-

\footnotetext{
${ }^{5} \S 3$ ust. 1 wspomnianych Wytycznych.

${ }^{6}$ Dz. Urz. L 198 z 22 lipca 1991 r., s. 1.
} 
mimo że ewolucja nastapiła w kierunku ujednolicenia zasad dotyczących kontroli i jednostek certyfikujących. Prawdą jest bowiem, że rozporządzenie (WE) nr 882/2004 z 29 kwietnia 2004 r. w sprawie kontroli urzędowych przeprowadzanych w celu sprawdzenia zgodności z prawem paszowym i żywnościowym oraz regułami dotyczącymi zdrowia zwierząt i dobrostanu zwierząt ${ }^{7}$ stanowi obecnie (przynajmniej aż do momentu jego zastapienia $^{8}$ ) punkt odniesienia wszystkich urzędowych kontroli w zakresie żywności, ponieważ ma zastosowanie zarówno w kontroli bezpieczeństwa żywności, jak i w kontroli dotyczących produktów wysokiej jakości: do rozporządzenia $\mathrm{nr} 882 / 2004$ odnoszą się art. $36 \mathrm{i}$ n. rozporządzenia nr 1151/2012, dotyczące wyznaczenia właściwych organów odpowiedzialnych za kontrole urzędowe.

Prawdą jest także, że „kodyfikacja” wprowadzona wspomnianym rozporządzeniem z 2004 r. znajduje swoją rację bytu bardziej w logice systemu bezpieczeństwa żywności aniżeli w rozszerzeniu modelu kontroli opracowanego w odniesieniu do procesów produkcyjnych w obrębie wszystkich działań podejmowanych w przedsiębiorstwie, w perspektywie kontroli działalności produkcyjnej niż w konieczności uproszczenia i ujednolicenia wszystkich zasad odnoszących się do kontroli żywności. Modele normatywne bowiem już opracowane dla produktów wysokiej jakości stanowiły przeważający parametr regulacyjny, który został rozszerzony także na kontrole w zakresie bezpieczeństwa produktów.

Jeśli chodzi o specjalny charakter przepisów dotyczących kontroli w zakresie certyfikacji produktów wysokiej jakości, już samo rozporządzenie nr 882/2004 stanowi, że ogólna regulacja powinna wykazywać niezbędną elastyczność, aby można ją było uczynić kompatybilną z produktami wysokiej jakości ${ }^{9}$. Uważna lektura rozporządzenia $\mathrm{nr}$ 1151/2012 pozwala zauważyć, że kontrole przewidziane dla tej kategorii produktów powinny przewidywać zgodność ze specyfikacją produkcji oraz monitorowanie stosowania zarejestrowanych nazw (art. $36 \S 3$ ). Dodatkowo krajowe plany kontroli powinny przewidywać specyficzną i odrębną sekcję

${ }^{7}$ Dz. Urz. L 191/1 z 30 kwietnia 2004 r.

${ }^{8}$ COM (2013), 265 def.: zob. http://ec.europa.eu/dgs/health_consumer/pressroom/animalplant-health_en.htm.

${ }^{9}$ Rozporządzenie nr 2092/91 w sprawie produkcji ekologicznej produktów rolnych oraz znakowania produktów rolnych i środków spożywczych, rozporządzenie $\mathrm{nr}$ 2081/92 w sprawie ochrony oznaczeń geograficznych i nazw pochodzenia dla produktów rolnych i środków spożywczych oraz rozporządzenie $\mathrm{nr}$ 2082/92 w sprawie świadectw o szczególnym charakterze dla produktów rolnych i środków spożywczych zawierają szczególne środki dla sprawdzenia zgodności z wymaganiami w nich określonymi. 
poświęconą temu segmentowi działań kontrolnych dotyczących przedsiębiorstw (art. 40).

Jeśli wziąć następnie pod uwage przypadek produkcji ekologicznej, to specyficzny charakter $\mathrm{w}$ definiowaniu instrumentów kontroli staje się jeszcze bardziej oczywisty. Szczegółowe przepisy dotyczące kontroli zostały zawarte nie tylko w rozporządzeniu (WE) nr 834/2007 z 28 czerwca 2007 r. w sprawie produkcji ekologicznej i znakowania produktów ekologicznych i uchylającego rozporządzenie (EWG) nr 2092/91 ${ }^{10}$ (artykuły 27-31), ale poświęcony jest im także cały tytuł IV rozporządzenia (WE) nr 889/2008 z 5 września 2008 r. ustanawiającego szczegółowe zasady wdrażania rozporządzenia Rady (WE) nr 834/2007 w sprawie produkcji ekologicznej i znakowania produktów ekologicznych w odniesieniu do produkcji ekologicznej, znakowania i kontroli ${ }^{11}$.

Ta intensywność regulacji wynika z faktu, że w odniesieniu do produkcji ekologicznej istnieje bardzo duża możliwość wystąpienia oszustwa $^{12}$. Przedmiotem certyfikacji są metody produkcji, które wykluczają użycie pestycydów, ale możliwe do sprawdzenia tylko przez monitorowanie czynności produkcyjnych na terenie przedsiębiorstwa. Nie można też powiedzieć, że skutki naruszenia zasad produkcji ekologicznej są zawsze możliwe do zauważenia w produkcie końcowym. Wydaje się, że punkt ciężkości systemu kontroli w istocie przesuwa się w stronę regulacji usług certyfikowania.

Punktem wyjścia staje się określenie działalności prywatnych podmiotów, które dokonują certyfikacji produkcji ekologicznej w charakterze czynności świadczenia usługi podlegającej prawom rynkowym: w tej sprawie orzekał już Trybunał Sprawiedliwości (wyrok C-393/05 z 29 listopada 2007 r.). Trybunał wykluczył, ażeby państwo członkowskie mogło wymagać, by prywatny podmiot akredytowany w zakresie dokonywania certyfikacji produkcji ekologicznej posiadał zakład lub inną stałą infrastrukturę na terytorium krajowym. Chodziło w tym przypadku o zastosowanie zasady swobody świadczenia usług, zgodnie z utrwaloną linią orzeczniczą. W celu uniknięcia barier rynkowych Trybunał wyjaśnił, że wystarczałoby wymaganie od podmiotów certyfikujących $\mathrm{z}$ siedzibą za

${ }^{10}$ Dz. Urz. L 189/1 z 20 lipca 2007 r.

${ }^{11}$ Dz. Urz. L 250 z 18 września 2008 r.

${ }^{12}$ Według art. $27 \S 3$ rozporządzenia $\mathrm{nr} 834 / 2007$ : „W kontekście niniejszego rozporządzenia charakter i częstotliwość przeprowadzania kontroli określa się na podstawie oceny ryzyka wystąpienia nieprawidłowości lub naruszeń zgodności z wymogami ustalonymi w niniejszym rozporządzeniu". 
granica, które złożyłyby wniosek o akredytację, dowodu posiadania odpowiedniego personelu i infrastruktury w państwie, w którym odbywałyby się kontrole. Należy mieć na uwadze, że wymiana informacji między państwami zgodnie z art. 10 rozporządzenia nr 2092/91 skompensowałby brak stałej siedziby w państwie, w którym działalność byłaby wykonywana.

Wreszcie, ustawodawstwo europejskie zawiera szczegółowe przepisy w zakresie wymiany informacji na temat przedsiębiorstw podlegających systemowi kontroli, które mają na celu ułatwienie kontroli, jeśli przedsiębiorstwo ekologiczne zamierza zmienić jednostkę certyfikująca, która przeprowadza certyfikację. Przewiduje się wiele reguł dotyczących wymiany informacji pomiędzy organami kontroli a jednostkami certyfikującymi, aby zapewnić skuteczność kontroli zarówno w sytuacji, gdy podmiot gospodarczy jest kontrolowany przez różne podmioty, jak i wtedy gdy podmioty gospodarcze lub ich podwykonawcy zmieniają organ kontrolny lub jednostkę certyfikującą (art. $92 \S 1$ i 2 rozporządzenia $n r$ 882/2008).

Aby umożliwić zmianę podmiotów, czyli współobecność jednostek certyfikujących $\mathrm{w}$ przedsiębiorstwie, rozporządzenie ustanawia odpowiednią dokumentację (,dokumentacja dotycząca kontroli”, art. 2 lit. s), mająca na celu wspieranie wymiany informacji dotyczących certyfikowanych przedsiębiorstw, a w konsekwencji narzuca państwom konieczność podjęcia „odpowiednich środków” oraz określenia ,udokumentowanych procedur $\mathrm{w}$ celu umożliwienia wymiany informacji między wszystkimi organami kontrolnymi, które wyznaczyły i/lub wszystkimi upoważnionymi jednostkami certyfikującymi” (art. 92 §).

$\mathrm{W}$ rzeczywistości jednak, biorąc pod uwage postanowienia omawianego rozporządzenia, wydaje się, że jego celem jest raczej zagwarantowanie zachowania „certyfikowanego rynku usług”, aniżeli zapewnienie rzeczywistej skuteczności kontroli, której poddawane są podmioty gospodarcze. Udostępnianie dokumentacji przedsiębiorstwa podlegającego systemowi kontroli ma w rzeczywistości na celu zachowanie ciagłości w przeprowadzanych kontrolach, a jednocześnie zagwarantowanie elastyczności wyboru podmiotowi gospodarczemu, a zatem ostatecznie obecności wielu podmiotów świadczących usługi certyfikujące na rynku. Może się to odbywać nawet kosztem realizacji ostatecznego celu rozporządzenia, którym powinna być skuteczna kontrola produkcji.

W tym miejscu należy postawić pytanie, do czego służy zwiększenie możliwości zmiany podmiotów certyfikujących, a przede wszystkim, czy środki te rzeczywiście służą zapewnieniu prawidłowego przebiegu działalności certyfikacyjnej z punktu widzenia realizacji celów rozporządze- 
nia. W rzeczywistości bowiem korzystanie z usług świadczonych przez jednostki certyfikujące ma na uwadze nie tyle prywatny interes podmiotu gospodarczego nastawionego na uzyskanie korzystniejszych warunków, ile raczej interes zbiorowości dotyczący przejrzystości certyfikacji produktu oraz gwarancji zastosowania metod produkcji ekologicznej.

Konkurencja między jednostkami certyfikującymi i namnożenie się prywatnych podmiotów kontrolnych, a tym samym stworzenie ,rynku usług", jest modelem odległym od systemu, który opiera się na certyfikacji, a w którym powierza się w pierwszej kolejności właśnie władzom państw członkowskich kontrolę nad działalnością przedsiębiorstw, a dopiero $\mathrm{w}$ dalszej - zawsze pod kontrolą władz publicznych - przekazanie tej władzy prywatnym podmiotom kontrolującym. System certyfikacji może jednak być stanowiony bezpośrednio przez organy administracyjne państwa członkowskiego (art. 27 § 1 i 4 rozporządzenia nr 834/2007). Obecność prywatnych podmiotów kontrolnych jest najbardziej praktycznym wyborem, ale nie jest to jedyne rozwiązanie zaproponowane w rozporządzeniu. Należy zauważyć, że ustawodawstwo włoskie starało się zmniejszyć negatywne skutki regulacji, która przewiduje możliwość zmiany jednostek certyfikujących. Zarządzenie dekretem ministerialnym DM 10071 z 2012 r. wprowadza w tym zakresie dwa ograniczenia: wymóg istnienia tylko jednej jednostki certyfikującej dla każdego przedsiębiorstwa (art. 1) oraz zakaz zmiany jednostki certyfikującej w przypadku, gdy zostaną stwierdzone nieprawidłowości po stronie przedsiębiorstwa (art. 2 pkt 4$)^{13}$.

Oczywiste jest, że takie środki ograniczające służą zmniejszeniu ryzyka wystapienia oszustw, ale nie rozwiązują problemu związanego z uciekaniem się do mniej rygorystycznych jednostek certyfikujących, w swego rodzaju „prześciganiu się w obniżaniu standardów”, w poszukiwaniu mniej wymagających jednostek certyfikujących. Ta sytuacja staje się jeszcze bardziej niebezpieczna w kontekście zwracania się do przedsiębiorstw, które znajdują się poza granicami kraju. Z pewnością ryzyko to nie zmaleje wraz z zastosowaniem europejskiego systemu akredytacji jednostek certyfikujących.

${ }^{13}$ Sytuacja ta została obszernie zinterpretowana w dokumencie ministerialnym z 22 lipca 2013 r. obejmującym wszystkie sytuacje, w których proces sprawdzania wystąpienia naruszenia został wszczęty, przy braku możliwości zmiany jednostki aż do momentu, w którym zostanie wydane postanowienie dotyczące niezgodności produktu z wymogami certyfikacji: „nie jest możliwa zmiana jednostki certyfikującej przy wystąpieniu jawnych i niewyjaśnionych niezgodności, również w przypadkach, w których są w toku procedury administracyjne lub trwają czynności dochodzeniowe, których skutkiem było wydanie tymczasowych postanowień". 
Tendencja do upraszczania zależności między przedsiębiorstwami certyfikującymi a przedsiębiorstwami podlegającymi systemowi kontroli, z korzyścią dla podmiotów, które dokonują certyfikacji, jest zauważalna także w nowym wniosku dotyczącym rozporządzenia w sprawie produkcji ekologicznej (w procesie zatwierdzania) ${ }^{14}$. Również w tym przypadku przepisy wydają się ukierunkowane na ułatwianie jednostkom certyfikującym działalności oraz rozwoju ich działalności usługowej. Poniżej podano kilka takich przykładów.

1) W art. 26 przewiduje się połączenie przedsiębiorstw w grupy: paradoksem jest jednak, że łączenie się przedsiębiorstw jest ułatwiane w związku z certyfikacją (podczas gdy na ogół łączenie jest brane pod uwagę w odniesieniu do rynków zbytu dla produktów, gdyż ma na celu poprawę skoncentrowania podaży jako instrumentu gospodarczego pomocnego przy wspieraniu działalności małych przedsiębiorstw). Połączenie drobnych producentów w celu uproszczenia działań wykonywanych przez jednostki certyfikujące wydaje się mieć tutaj za rzeczywisty cel (nawet jeśli ukryty pod pretekstem obniżenia kosztów dla małych przedsiębiorstw) uproszczenie działań wynikających z usług certyfikacyjnych, które wprawdzie powinny bardziej umacniać system, aniżeli zarysowywać się jako klucz do zrozumienia tego obszaru rynku.

2) W art. 29 wniosek dotyczący rozporządzenia wprowadza kolejny element uproszczenia działań jednostek certyfikujących, które pierwotnie uzyskiwały akredytację dla poszczególnych krajów, teraz natomiast mogłyby działać obojętnie w zakresie wszystkich produktów pochodzących z krajów trzecich. Oczywiste jest, nawet jeśli akredytacja pociaga za sobą ocenę instrumentów niezbędnych do przeprowadzenia kontroli na miejscu, że u podstaw tego wyboru znajduje się idea ponadnarodowej instytucji certyfikującej, która przybliża się coraz bardziej do modelu prywatnych jednostek certyfikujących (operatywnych na obszarach działania ponadnarodowej interwencji). Wystarczy pomyśleć o certyfikacji w globalnej sieci dystrybucji, a oddala się od pierwotnego schematu jednostki certyfikującej poddawanej bezpośredniej kontroli państw członkowskich. Zresztą zasady dostępu do certyfikacji tych podmiotów nie są jeszcze nawet zdefiniowane we wniosku dotyczącym podstawowego rozporządzenia dla rolnictwa ekologicznego, a tylko odsyłane do późniejszych aktów wykonawczych Komisji.

Wyłania się wreszcie ostatni aspekt dotyczący rozważanej kwestii, który dotyczy roli państw członkowskich w procesie kontroli działalności

\footnotetext{
${ }^{14}$ COM (2014), 180 final z 24 marca 2014 r.
} 
certyfikujących, ta bowiem stopniowo się osłabia. Wychodząc poza powyższe rozważania dotyczące możliwego przejęcia działalności kontrolnych bezpośrednio przez władze publiczne, sama odpowiedzialność państw członkowskich, wobec nadzoru nad prywatnymi jednostkami certyfikującymi, jest obecnie pośrednia również w wyniku zaangażowania wspomnianej instytucji, która zapewnia akredytację jednostek certyfikujących, zgodnie z rozporządzeniem (WE) $\mathrm{nr}$ 765/2008 z 9 lipca $2008 \mathrm{r}$. ustanawiającego wymagania w zakresie akredytacji i nadzoru rynku odnoszące się do warunków wprowadzania produktów do obrotu i uchylające rozporządzenie (EWG) nr 339/93 ${ }^{15}$.

Wpływa to nie tylko na początkowy etap akredytacji, ale także na monitorowanie działalności certyfikujących w świetle rozporządzenia nr 882/04.

W rzeczywistości art. 92 quater rozporządzenia nr 889/2008, wprowadzony przez rozporządzenie (UE) nr 392/2013 z 29 kwietnia 2013 r. zmieniające rozporządzenie (WE) nr 889/2008 w odniesieniu do systemu kontroli produkcji ekologicznej ${ }^{16}$ zajmuje się uszczegółowieniem treści nadzoru, który powinny sprawować właściwe władze (publiczne). Przedmiot nadzoru ,zasadza się głównie na ocenie efektywnych świadczeń takich organów kontroli, biorąc pod uwagę rezultaty pracy krajowych organów akredytacji".

W ten sposób deleguje się ocenę prywatnych jednostek certyfikujących (ostatni element, który przynależał organom kontrolnym państwa członkowskiego) organowi technicznemu, który spełnia parametry wyznaczone przez UE w zakresie jednolitości zasad technicznych dotyczących akredytacji. Ten element (choć zależy bezpośrednio od rządu - we Włoszech: Accredia) plasuje się pomiędzy państwem a jednostkami certyfikującymi w odniesieniu do oceny zgodności, którą rozporządzenie nr 834/2007 nadal powierza, przynajmniej teoretycznie, organom kontrolnym wyznaczonym przez państwo członkowskie.

Ostatnia uwaga dotyczy skutków takiej „elastyczności” na korzyść jednostek certyfikujących dla roli państw członkowskich w procesie regulacji systemu produkcji ekologicznej. Przy okazji wprowadzenia „krajowego logo" produkcji ekologicznej, co było nowością w rozporządzeniu z 2007 r., uznano za właściwe sprowadzenie tej możliwości (anormalnej, gdy się nad tym dobrze zastanowić, w rozporządzeniu nastawionym na ujednolicenie techniki produkcji) do okoliczności, w których jednostki

\footnotetext{
${ }^{15}$ Dz. Urz. L 218/30 z 18 sierpnia 2008 r.

${ }^{16}$ Dz. Urz. L z 30 kwietnia 2013 r.
} 
certyfikujące podlegałyby nadal odpowiedzialności krajowych władz publicznych, zarówno w zakresie upoważnienia do wykonania swoich obowiązków, jak i w odniesieniu do kontroli audytowej. Zważywszy, że obecnie audyt również został ujednolicony na poziomie europejskim, a jednostki certyfikujące można $\mathrm{z}$ łatwością zmienić, nawet jeśli znajdują się poza granicami kraju, nasuwa się pytanie, czy również i ten przepis - którym ustawodawca zaznaczył „krajową” wagę rolniczej produkcji ekologicznej - nie powinien już zostać uznany za „będący na wymarciu”.

\title{
CERTIFICATION AND QUALITY PROTECTION OF AGRICULTURAL FOOD PRODUCTS
}

Sum mary

Certification of agricultural food products is a dynamically developing economic phenomenon which constitutes a response to the demands articulated by consumers seeking information about products and their production process. The authoress claims, however, that instead of ensuring an efficient control of food producers, the goal of Regulation $882 / 2008$ seems to rather guarantee a 'certified service market' enabling development and creation of a large number of certifying agencies, which subsequently abound in the market and compete with one another. This phenomenon has also been mentioned in the new petition regarding the Regulation of ecological production, in which this greatly simplified relation today between certifying entities and those controlled, to the advantage of the former, has been noted.

\section{CERTIFICAZIONE E TUTELA DELLA QUALITÀ DEI PRODOTTI AGROALIMENTARI}

\author{
Riassunto
}

La certificazione dei prodotti agroalimentari di qualità rappresenta un fenomeno economico in forte espansione, che risponde all'esigenza dei consumatori di poter fare affidamento sulle caratteristiche dei prodotti legate al processo di produzione. L'autrice afferma tra l'altro che - a quanto pare - l'obiettivo del regolamento 882/2008 è piuttosto quello di garantire il mantenimento di un "mercato di servizi di certificazione" che di assicurare l'effettività dei controlli sugli operatori. La concorrenza tra organismi di certificazione e la proliferazione dei soggetti privati di controllo, e quindi la creazione di un "mercato di servizi", è un modello distante da un sistema che si basa sulla certificazione e che affida, in prima istanza, alle autorità degli Stati membri il controllo sull'attività delle aziende. Una tendenza alla semplificazione nei rapporti tra imprese di certificazione e imprese controllate, a vantaggio dei soggetti che effettuano la certificazione, si rinviene anche nel nuovo progetto di regolamento sulla produzione biologica. 